\title{
Fuel Properties of Butanol - Hydrogenated Vegetable Oil Blends as a Diesel Extender Option for Internal Combustion Engines
}

\author{
Máté Zöldy ${ }^{\text {* }}$ \\ 1 Department of Automotive Technologies, Faculty of Transportation Engineering and Vehicle Engineering, \\ Budapest University of Technology and Economics, H-1521 Budapest, P. O. B. 91, Hungary \\ * Corresponding author, e-mail: mate.zoldy@gjt.bme.hu
}

Received: 05 April 2019, Accepted: 20 June 2019, Published online: 01 October 2019

\begin{abstract}
European legislation and new engine technologies require better quality in fuels, and the diesel scandal pushes engine and fuel developers to investigate new solutions. The decrease of fossil energy sources and the new, stricter emission regulations necessitate the discovery of renewable sources. Biofuels are an obvious solution to replace fossil fuels in a more environmentally conscious way. This study presents a new approach with the analytical investigation of butanol, hydrogenated vegetable oil, and diesel oil blends. In the presented phase of the research, our focus was on the most application- critical chemical properties of the fuels, to analyze if the three component blends are suitable for compression ignition engines. A wide-ranging chemical-analytical test plan was prepared with nearly 20 parameters measured of the chemical and physical parameters of blends, especially regarding flash point, cetane number, viscosity and cold filter plugging point (CFPP).

The findings prove that from an engine-critical characteristics point of view butanol - hydrogenated vegetable oil - diesel blends are a potential solution, as HVO and butanol counterbalance its critical parameters.
\end{abstract}

\section{Keywords}

butanol, hydrogenated vegetable oil, diesel extenders, analytical testing

\section{Introduction}

The continuous increase of fuel demand, simultaneous with the decrease of natural resources and the diesel scandal have increased the focus on new fuels and blending component development for compression ignition engines. Bio components are very frequently blended with crude oil based fuels; most commonly ethanol with gasoline and vegetable oil methyl esters with diesel. The advantage of using biofuels is that their reproduction cycle is much shorter than that of crude oil, a year or even a few months [1]. The closed carbon-dioxide cycle of biofuels is the basis for decreasing the greenhouse effect of transport [2]. Many raw materials and technologies can be used to produce biofuels. Fatty-AcidMethyl-Ester or FAME is the most commonly used diesel substitute $[3,4]$ and in most of the cases it is produced from a vegetable oil basis [5] (but also from animal fat [6]). However, diesel is the most important fuel of mobility, so the search for substitute bio-components is a priority. Hydrogenated Vegetable Oils (HVO) can be produced by hydrocracking of vegetable oils to produce components with high cetane number and as a result of isomerization, they have extraordinary cold flow properties as well. Alcohols could help to reduce $\mathrm{NO}_{\mathrm{x}}$ emissions, and as they do not contain aromatics, their particle emissions are more favorable as well. Due to its very low flash point and density, ethanol is difficult to use as a diesel blending component, despite the advantage that it can be produced from the non-edible parts of plants. Butanol has better potential based on its higher density and higher flash point. Two common methods for producing $n$-butanol are starch fermentation with bacteria and crotonaldehyde-based catalytic hydrogenation.

Harmonizing their chemical properties with internal combustion engines is a rather challenging task for the automotive and petroleum industry. The increasing demand for diesel and the simultaneously decreasing demand for gasoline in Europe put focus on the topic of how the ratio of renewable extenders in diesel could be increased [7]. Butanol and hydrogenated vegetable oil are one of the second-generation biofuels that can be suitable as blending components 
of diesel. Butanol has characteristics that are nearer to diesel than to ethanol, and hydrogenated vegetable oils have the benefits of standard quality and extremely good winter behavior to FAME based biodiesels [8].

The most significant factor for an assessment of an automotive fuel is its potential to increase engine efficiency, its positive effect on emissions and extend resource pool to decrease the dependency on decreasing crude oil reserves. As these factors are also closely connected with engine and vehicle technology and especially the exhaust gas after-treatment technology, it is practical to have a differentiation between newer and older technologies, which represent most of the existing vehicle fleet and modern, state-of-the-art vehicles. It is also essential that the new fuels deliver at least similar drivability performance as current fuels. The same is true for extreme climate conditions like hot and cold temperatures and high altitudes. New fuel blends should also be typical and compatible with the materials of engines and tank systems.

Researches that aim to extend diesel pool have become more prevalent since the oil crisis of the 1970's. There are studies and applications with fuels gaseous at normal temperature, to use them in internal combustion engines [9], but with liquid substitutes there seem to be a variety of more suitable solutions. Methyl ester based bio components are broadly used in Europe and elsewhere. With the esterification process, the characteristics of vegetable oils, animal fat oils or even used cooking oil can be transformed into those similar to fossil diesel. The limitation of utilization of these bio components is the injector system, where the producers in most of the cases set maximum $7 \mathrm{v} / \mathrm{v} \%$ (volumetric percentage) limitation [10-12].

Vegetable oils direct blending to the fuel of state-ofthe-art engines is not an option, due to the fundamental differences between the characteristics of vegetable oil and diesel oil.

Stricter emission regulations gave a rise to ethanol utilization opportunities in compression ignition engines. The main barriers were keeping the diesel and ethanol emulsified, and managing the relatively low friction of ethanol. Ethanol is not a very good option for blending, based on its low heating value, low boiling point, and the fact that first generation production means a race with the domestic food industry for resources. Butanol could be a better option utilized as a diesel extender. It has a higher cetane number than ethanol, with its boiling temperature is above $117^{\circ} \mathrm{C}$, it has better solubility and it has a heating value which is $80 \%$ of diesels.
It seems to be a good solution to use a tri-blend: ethanol-biodiesel and fossil diesel mixtures. In these, the biodiesel helps blend ethanol with diesel as it acts as an emulsifier. Results of numerous investigations, [13-16] showed that the bioethanol-biodiesel-diesel blends fulfil the cetane number, viscosity and lubricity requirements for standard diesel. The practical measurement, the engine bench tests showed that utilization of the new fuel decreases the emissions of the engine.

Many tests were carried out with diverse butanol-diesel blends. Most of these tests were done on single cylinder engines [17-20], some of them on test engines [21] and on a test vehicle [22]. The tests investigated the butanol's effect on emission and engine utilization properties. The main aim of our test was the analytical test of combustion- and handling related parameters.

The tests were focused on low percentage butanol mixtures, they included a number of blends, ranging from $5 \mathrm{v} / \mathrm{v} \%$ butanol content $[17,21]$ up to $40 \mathrm{v} / \mathrm{v} \%[18,22]$, the bulk of the tested fuels contained $10-20 \mathrm{v} / \mathrm{v} \%$ butanol.

The BP-DuPont biofuels fact sheet [23] summarizes the main characteristics of butanol as a fuel blending component. In the compression ignition engine utilization, the crucial factor is that it has a higher energy density than ethanol, approximately $80 \%$ of diesels. It is also less volatile than ethanol. It is not as corrosive, so there are no issues with higher concentrations, such as its tendency to corrode aluminum or polymer components in fuel and dispensing systems. It is also less hydroscopic, so it can be transported through pipelines.

Karabektas and Hosoz [21] found that the latent heat of vaporization and the specific gravity of isobutanol are very close to the properties of diesel fuel. The main obstacle of isobutanol as a direct replacement of diesel fuel is its low cetane number, which may deteriorate the auto ignition capability of the fuel injected.

Smith and Workman [24] note that its latent heat is almost the same as the latent heat of octane. Butanol can be mixed with diesel fuel in virtually any concentration. It does not separate when mixed with water, or with cooling. Furthermore, it does not have significant effect on cetane number of diesel fuel. In blends with diesel fuel, butanol tends to reduce the solidification temperature of the fuel at low temperatures.

Laza et al. [19, 20] carried out tests with rapeseed oil and butanol mixtures. They found that $1 \%$ isobutanol decreases the cetane number of the blend by $0.8 \%$ on average. Due to the lower cetane number the combustion was 
delayed. The assumption had been that one of the main advantages of butanol would be that the viscosity of the samples would decrease by a higher percentage of alcohol additives. It means better pumping ability in the diesel fuel pump. As the cetane number decreases with higher alcohol content, as much as $10 \%$ alcohol content can be introduced in older diesel engines.

The brake-specific fuel consumption increases with the addition of alcohol. Alcohol fuels contain oxygen, so this will improve combustion, but power decreases due to lower calorific value compared with diesel, so using alcohol in large quantities is not favorable [13].

Smith and Workman [24] state that the solidification temperature of a mixture reduces with the addition of butanol and it does not separate in lower temperatures. They also found that butanol is the least likely to cause starting difficulties or problems if warmed.

Investigations with butanol - hydrogenated vegetable oil - diesel blends are typically focused on in-engine behavior $[25,26]$. For a better understanding of the combustion of different mixtures, our aim was to map the blends first and utilize these results later on during the combustion analysis. Deeper analysis is not only a tool to understand ignition and engine application relevant characteristics but test parameters that can be critical during the product handling.

\section{Experimental}

In this phase of the research, most combustion and handling relevant chemical parameters of butanol - HVO - diesel blends were measured. Viscosity, cetane number, CFPP and flash point were the most important factors in engine application point of view among the 20 investigated characteristics. Concentration of the blends was chosen on the one hand based on former experiments on butanol-diesel blends [27]. This research showed that butanol in this blending ratio changes the characteristic of the fuel in some cases dramatically and the assumption was that with HVO blending in the same range could compensate it. On the other hand the experience of introducing diesel extenders in the fuel market is as well starts in small portions (i.e. FAME / biodiesel introduction in Europe). Main reason of this is the higher producing cost of the alternative component compared to fossil diesel. Proposition of the measured blends and the blends code are presented in Table 1 .

In the near future, engine bench test measurements are planned to have a real picture on fuel consumption and emission characteristics. Table 2 shows the properties of the blending components.
Table 1 Measured blends

\begin{tabular}{lccccc}
\hline $\begin{array}{l}\text { Butanol content / } \\
\text { HVO content }\end{array}$ & $\begin{array}{c}2.5 \\
\mathrm{v} / \mathrm{v} \%\end{array}$ & $\begin{array}{c}5 \\
\mathrm{v} / \mathrm{v} \%\end{array}$ & $\begin{array}{c}7.5 \\
\mathrm{v} / \mathrm{v} \%\end{array}$ & $\begin{array}{c}10 \\
\mathrm{v} / \mathrm{v} \%\end{array}$ & $\mathrm{v} / \mathrm{v} \%$ \\
\hline $0 \mathrm{v} / \mathrm{v} \%$ & $\mathrm{~A}$ & $\mathrm{~B}$ & $\mathrm{C}$ & $\mathrm{D}$ & $\mathrm{E}$ \\
$2.5 \mathrm{v} / \mathrm{v} \%$ & & $\mathrm{~F}$ & $\mathrm{G}$ & $\mathrm{H}$ & $\mathrm{I}$ \\
$5 \mathrm{v} / \mathrm{v} \%$ & & $\mathrm{~J}$ & $\mathrm{~K}$ & $\mathrm{~L}$ & $\mathrm{M}$ \\
$7.5 \mathrm{v} / \mathrm{v} \%$ & & $\mathrm{~N}$ & $\mathrm{O}$ & $\mathrm{P}$ & $\mathrm{Q}$ \\
$10 \mathrm{v} / \mathrm{v} \%$ & $\mathrm{R}$ & $\mathrm{S}$ & $\mathrm{V}$ & $\mathrm{W}$ \\
\hline
\end{tabular}

Table 2 Measured blends

\begin{tabular}{lccc}
\hline & diesel & butanol & HVO \\
\hline Viscosity $40{ }^{\circ} \mathrm{C}\left(\mathrm{mm}^{2} / \mathrm{s}\right)$ & 2.9 & 2.22 & 3.2 \\
Flash point $\left[{ }^{\circ} \mathrm{C}\right]$ & 69 & 29 & 99 \\
Cetane number & 51 & 25 & 87 \\
CFPP $\left[{ }^{\circ} \mathrm{C}\right]$ & $-5{ }^{\circ} \mathrm{C}$ & below $-40{ }^{\circ} \mathrm{C}$ & $-20{ }^{\circ} \mathrm{C}$ \\
Lubricity at $60{ }^{\circ} \mathrm{C}(\mathrm{um})$ & $<460$ & 591 & $<460$ \\
Density $\left[\mathrm{kg} / \mathrm{m}^{3}\right]$ & 838 & 810 & $778-785$ \\
\hline
\end{tabular}

\section{Results}

\subsection{Viscosity}

Viscosity measurements were done according to ISO/DIS 3104 [27]. This standard gives a specification for the determination of kinematic viscosity of liquid crude oil originated products, both clear and solid, by measuring time for a volume of liquid that flows under gravity through a calibrated glass capillary viscometer. Dynamic viscosity could be acquired by multiplying the measured kinematic viscosity by the test sample density. The main test principle of ISO/DIS 3104 is that time is measured for a fixed volume of fluid to flow under gravity through the capillary of a calibrated viscometer under a reproducible driving head, at a certain and carefully controlled temperature. Kinematic viscosity is the product of the measured flow time and the calibration constant of the viscometer. The repeatability of the test with the test fuels is $0.004 \mathrm{~mm}^{2} / \mathrm{s}$, the reproducibility is $0.003 \mathrm{~mm}^{2} / \mathrm{s}$ in the test range [28].

Butanol's effect on a blend's viscosity is shown on Fig. 1. Increase of butanol content with $1 \%$ causes app. $1.4 \%$ decrease in viscosity. It is slightly higher than the $1.2 \%$ reported in [29]. As expected, viscosity is nearly neutral on HVO blending. The viscosity decrease in test range is nearly linear and it can be described by Eq. (1):

$V i s c_{\text {blend }}=-0.03 * X_{B u}+0.01 * Y_{\mathrm{HVO}}+V i s c_{r e f}$

where Visc $_{\text {blend }}$ stands for viscosity of the investigated blend, $X_{B u}$ represents the volumetric share of butanol and $Y_{\text {HVO }}$ stays for the volumetric share of HVO in the blend. $V_{i s c_{r e f}}$ is the viscosity of the reference fuel. 


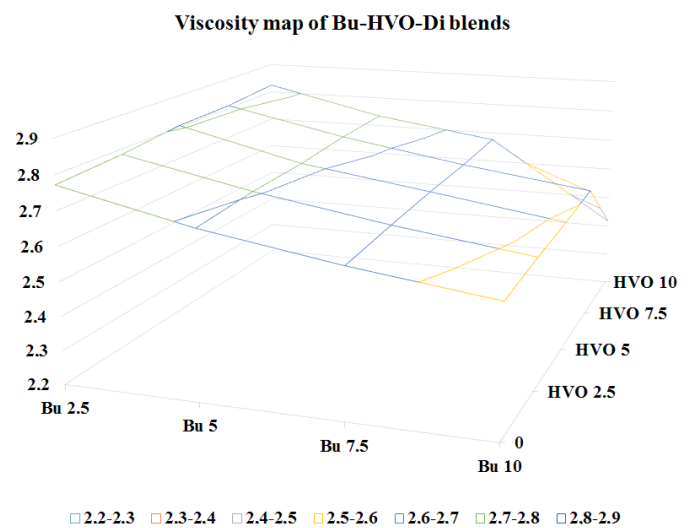

Fig. 1 Butanol and HVO merged effect on a blend's viscosity

From a utilization perspective, the result shows that butanol and HVO joint blending has a slight, decreasing effect on a blend's viscosity in tested ratios. The blends could be used as compression ignition engine fuels due to their viscosity parameters.

Laza el al. $[19,20]$ arrived at similar results when mixing butanol and pure rapeseed oil.

\subsection{Flash point}

Measurements were carried out according to the prescriptions of DIN EN ISO 2719. Flash point is the lowest temperature of the test sample, corrected to a barometric pressure of $101.3 \mathrm{kPa}$, at which the application of an ignition source causes the vapor of the sample to ignite and the flame to spread across the surface of the liquid within the test specifications [29].

The tested blend was placed in a Pensky-Martens test cup, and it was heated to reach a steady temperature increase with continuous stirring. An ignition source was directed through an opening in the test cup lid at regular temperature intervals with a simultaneous interruption of the stirring process. The lowest temperature (at which the application of the ignition source causes the vapor of the tested material to ignite and spread over the surface of the liquid) is recorded as the flash point at the ambient barometric pressure. This temperature is corrected to standard atmospheric pressure using an equation.

Tests repeatability with the test fuels is $1.27{ }^{\circ} \mathrm{C}$, the reproducibility is $2.76^{\circ} \mathrm{C}$ in the test range.

Effect of the co-blending could be described by Eq. (2):

$F P_{\text {blend }}=-0.77 * X_{B u}+0.05 * Y_{\mathrm{HVO}}+F P_{\text {ref }}$

where $F P_{\text {blend }}$ stands for flash point in ${ }^{\circ} \mathrm{C}$ of the investigated blend, $X_{B u}$ represents volumetric share of butanol and $Y_{\mathrm{HVO}}$ stays for volumetric share of $\mathrm{HVO}$ in the blend. $F P_{\text {ref }}$ is the flash point of the reference fuel.
Blending butanol decreases the blend's flash point to around to $40{ }^{\circ} \mathrm{C}$ as pictured in Fig. 2, as expected according to [28]. It is under the standard minimum of $55^{\circ} \mathrm{C}$ [29]. This decrease is critical regarding transportation / logistics, as it means that butanol-diesel blends have to be handled as flammable materials, like gasoline. It necessitates an upgrade in the security equipment of diesel supply chains or the new blend needs to be transported in the gasoline supply chain.

\subsection{Cetane Number}

Cetane Number $(\mathrm{CN})$ could be one field where the expected effect of butanol and HVO can compensate each other. As butanol has a lower cetane number than diesel and HVO has a much higher cetane number, we had a prognosis of various cetane number changes. Tests were carried out according to ISO 5165:1998 [30] standard. This set up the rating of the compression ignition engine fuel in terms of an arbitrary scale of cetane numbers using a standard single cylinder, four-stroke engine with variable compression ratio and indirect fuel injection.

Cetane number delivers a measure of ignition characteristics of tested liquids in compression ignition engines. It is determined at fixed engine speed in a pre-combustion chamber compression ignition engine. Test procedure is applicable for entire scale range from $0 \mathrm{CN}$ to $100 \mathrm{CN}$ but usual testing is between range of $30 \mathrm{CN}$ and $65 \mathrm{CN}$. The repeatability of the test with the test fuels is $0.85-1 \mathrm{CN}$, the reproducibility is $3.7-4.6 \mathrm{CN}$ in the investigated range.

Results presented in Fig. 3 showed the same tendency as in [12]; that one percentage butanol decreases the blends $\mathrm{CN}$ by $0.5 \mathrm{CN}$ point. Test results confirmed that cetane numbers can be handled as linear characteristics in diesel blending: every $1 \%$ increase in $\mathrm{HVO}$ content increased the blends $\mathrm{CN}$ with an average of $0.4 \mathrm{CN}$.

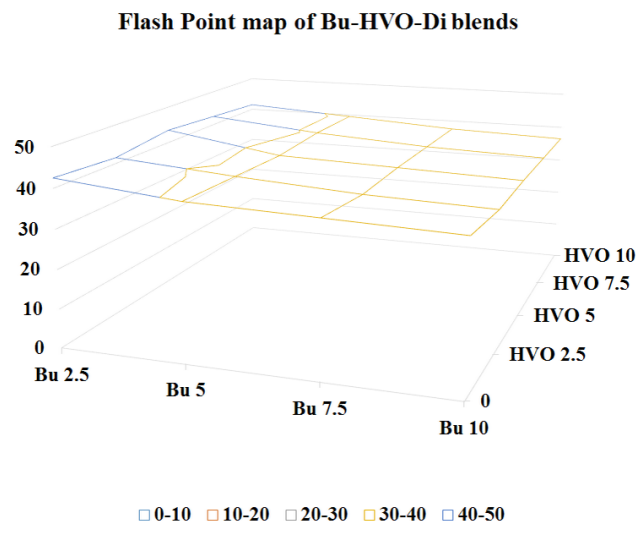

Fig. 2 Butanol - HVO joint blending effect on blend's flash point 


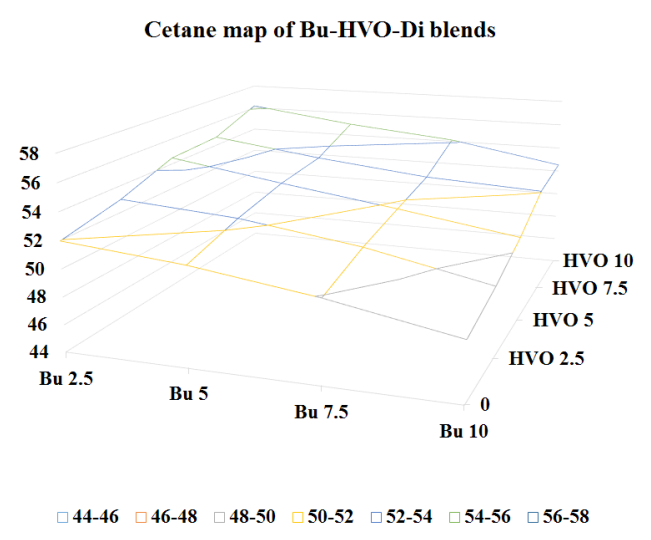

Fig. 3 Butanol - HVO blending effect on blend's cetane number

The lowering effect could be described by Eq. (3):

$$
\mathrm{CN}_{\text {blend }}=-0.47 * X_{B u}+0.40 * Y_{\mathrm{HVO}}+\mathrm{CN}_{\text {ref }}
$$

where $\mathrm{CN}_{\text {blend }}$ stays for cetane number of the investigated blend, $X_{B u}$ represents volumetric share of butanol and $Y_{\mathrm{HVO}}$ stays for volumetric share of $\mathrm{HVO}$ in the blend. $\mathrm{CN}_{\text {ref }}$ is the cetane number of the reference fuel.

In fuel blending, this $\mathrm{CN}$ decreasing effect suggests a high $\mathrm{CN}$ diesel fuel, used as base fuel or $\mathrm{CN}$ improver additives have to utilize to hold the standard values [31]. Our results with butanol are similar to the observation of Laza et al. [19, 20], as they found $0.8 \%$ decrease with increasing butanol content in rapeseed.

\subsection{Cold Filter Plugging Point}

CFPP (Cold Filter Plugging Point) is the highest temperature at which a given volume of fuel passes through a standardized filtration device in a prescribed time, when cooled down with prescribed parameters. CFPP measurement should be carried out according to MSZ EN 116:1999 [32]. This test describes the method for the determination of CFPP of diesel and heating oil fuels, using either manual or automated test equipment. Manual automated test equipment is both suitable for referee purposes. MSZ EN 116:1999 is valid to pure crude based distillate fuels, and fuels containing a flow-improving, anti-settling or other additives, intended for use in vehicles internal combustion engines and heating oil installations.

Results gained from the standard specified method are suitable for approximating the lowest temperature at which a fuel will give trouble-free flow in the fuel system.

The basis of the test principle is that the test a fuel sample is cooled under the specified conditions and is drawn into a pipette under a controlled vacuum, through a standardized wire mesh filter. The test procedure should be repeated, whilst the test fuel continues to cool down, for each ${ }^{\circ} \mathrm{C}$ below the first test temperature. Testing should be continued until the amount of wax crystals, which have been separated out of the solution, is sufficient to stop or slow down the flow of the tested liquid, that is if the time taken to fill the pipette exceeds $60 \mathrm{~s}$ or the fuel fails to return completely to the test jar before the fuel has cooled by a further $1{ }^{\circ} \mathrm{C}$. The indicated temperature at which the last filtration was carried out will be recorded as the cold filter plugging point.

The repeatability of the test with the test fuels is $1^{\circ} \mathrm{C}$, the reproducibility is $4{ }^{\circ} \mathrm{C}$ in the test range.

Adding more butanol into the Bu-HVO-Di blend a slight improvement was detected from the CFPP level of $-13{ }^{\circ} \mathrm{C}$ up to $-15{ }^{\circ} \mathrm{C}$ with $10 \%$ of butanol according to Fig. 4. However, it falls within the measurement failure range $\left(4^{\circ} \mathrm{C}\right)$. As HVO level was a bit lower than base fuel $\left(-12{ }^{\circ} \mathrm{C}\right)$, a linear characteristic was shown in the results. It means that a $\mathrm{HVO}$ with extra good winter qualities has the possibility to improve blends' winter abilities.

In practical utilization terms it means that butanol blending into fossil diesel offers a small improvement on cold flow properties, as a result the amount of cold flow improver additives can be decreased.

\subsection{Lubricity}

High Frequency Reciprocating Rig (HFRR) test was carried out according to ISO 12156-1:2016 [33]. This testing procedure specifies a method utilizing the High Frequency Reciprocating Rig. The aim is to assess the lubricating property of pure and additised diesel fuels. The standard defines two methods for measurement of the wear scar on a ball at $60{ }^{\circ} \mathrm{C}$ with a load of $200 \mathrm{~g}$ and duration of 75 minutes. Method "A" is designed for digital cameras and Method "B" is prepared for visual observation [34].

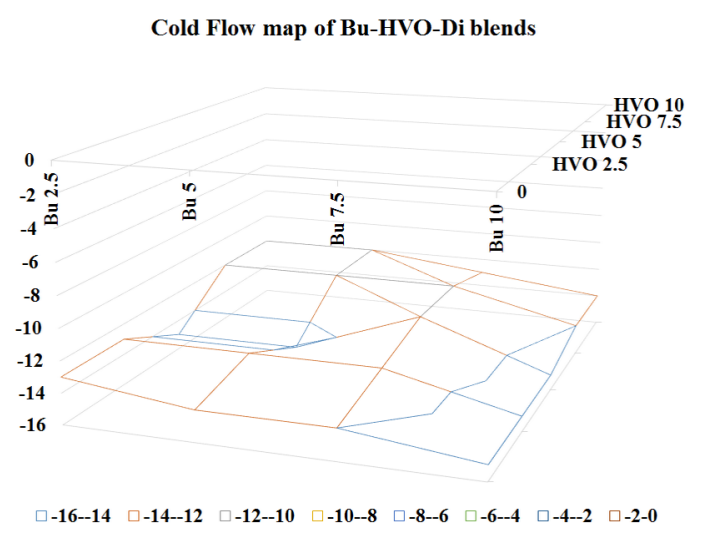

Fig. 4 Butanol - HVO blending effect on blend's CFPP number 
First blending butanol molecules have definitely decreased lubricity characteristics of the base diesel by nearly $40 \%$. Further adding of butanol has additional decreasing effect, but it was not so dramatic. Four times more butanol in the blend (an increase from $2.5 \mathrm{v} / \mathrm{v} \%$ to $10 \mathrm{v} / \mathrm{v} \%$ ) was followed by only app. $6 \%$ commutative HFRR decrease. Adding HVO to the blends had a billowy effect as see on Fig. 5. Some HVO containing blends as HVO 5 have slightly improved HFRR value with most butanol blends, but others as HVO 2.5 and HVO 7.5 blends had a reverse effect. However, the repeatability is $63 \mu \mathrm{m}$, and reproducibility is $102 \mu \mathrm{m}$ of the test and the mentioned differences are within this range.

\subsection{Density}

Density measurements were carried out according to the ISO 12185:1996 [35] test. Density has a primary impact on the energy content of the fuels, and through that, on fuel consumption. It is measured with aerometers in accordance to the theory of flexural vibration. A pipe is bent into a U-shape is filled with a small amount of test fuel under the investigation. The pipe is then vibrated and the resulting resonant frequency is measured and converted into a density value.

Density measurements resulted, as it was expected, in a linear change according to butanol and hydrogenated vegetable oil components density and blending volume. These results are presented in Fig. 6 in $\left[\mathrm{kg} / \mathrm{m}^{3}\right]$.

The effect of the co-blending could be described by Eq. (4):

$$
\text { Dens }_{\text {blend }}=-0.32 * X_{B u}-0.55 * Y_{\mathrm{HVO}}+\text { Dens }_{\text {ref }}
$$

where Dens $_{\text {blend }}$ stands for the investigated blends' density, $X_{B u}$ represents the volumetric share of butanol and $Y_{\mathrm{HVO}}$ stays for the volumetric share of HVO in the blend. Dens $_{r e f}$ is the reference fuel's density.

Lubricity (HFRR) map of Bu-HVO-Di blends

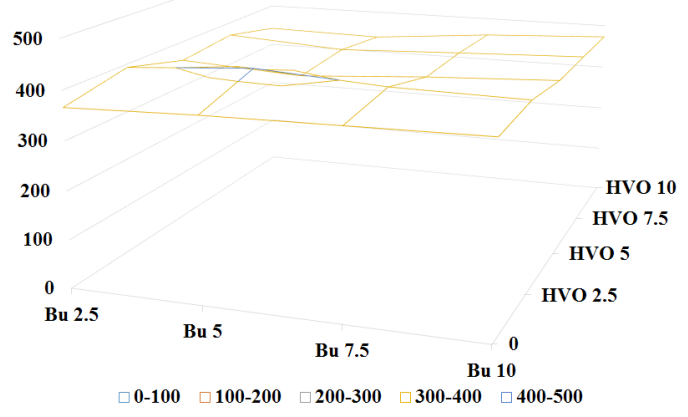

Fig. 5 Butanol - HVO blending effect on lubricity

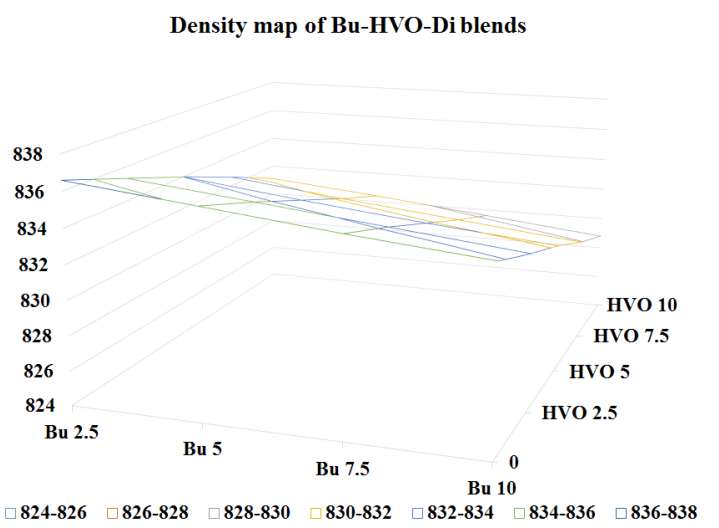

Fig. 6 Butanol - HVO blending effect on blends density

\section{Conclusions}

As the result of our investigations of chemical parameters, it can be concluded that from an engine-critical characteristics perspective butanol-hydrogenated vegetable oil-diesel blends are a potential solution. HVO and butanol are counterbalancing their effect on base fuels critical parameters.

The results are validating our expectations before the blending.

Increase of butanol content with $1 \%$ causes an approx. $1.4 \%$ decrease in viscosity and as it was expected, viscosity is nearly neutral on HVO blending. Flash point change is the only aspect according to our results, where the blends should be managed differently from normal diesel. Blending butanol decreases the blend's flash point to around to $40{ }^{\circ} \mathrm{C}$. One percentage butanol decreases the blends $\mathrm{CN}$ by $0.5 \mathrm{CN}$ point. Test results confirmed that cetane number can be handled as linear characteristics in diesel blending: every $1 \%$ increase in HVO content increased the blends $\mathrm{CN}$ with an average of $0.4 \mathrm{CN}$. Adding more butanol into the Bu-HVO-Di blend, a slight improvement was detected from the CFPP level of $-13{ }^{\circ} \mathrm{C}$ up to $-15{ }^{\circ} \mathrm{C}$ with $10 \%$ of butanol. However, it falls within the measurement failure range $\left(4^{\circ} \mathrm{C}\right)$. As $\mathrm{HVO}$ level was a bit lower than base fuel $\left(-12^{\circ} \mathrm{C}\right)$, a linear characteristic was shown in the results. Blends density had a slight decreasing tendency with the increase of renewable components.

Our research showed that the utilization of butanol -HVO - diesel blends as a diesel extender could be a very beneficial solution, if the problems of flash point decrease can be handled in the logistic chain. As a further step we plan to investigate blends in an engine bench, to see effect on emissions and fuel consumption. 


\section{References}

[1] Racz, L., Fozer, D., Nagy, T., Toth, A. J., Haaz, E., Tarjani, J. A., .. Mizsey, P. "Extensive comparison of biodiesel production alternatives with life cycle, PESTLE and multi-criteria decision analyses", Clean Technology and Environmental Policy, 20(9), pp. 2013-2024, 2018.

https://doi.org/10.1007/s10098-018-1527-1

[2] Horváth, I. T., Cséfalvay, E., Mika, L. T., Debreczeni, M. "Sustainability Metrics for Biomass-Based Carbon Chemicals", ACS Sustainable Chemistry \& Engineering, 5(3), pp. 2734-2740, 2017. https://doi.org/10.1021/acssuschemeng.6b03074

[3] Csefalvay, E., Horvath, I. T. "Sustainability Assessment of Renewable Energy in the United States, Canada, the European Union, China, and the Russian Federation", ACS Sustainable Chemistry \& Engineering, 6(7), pp. 8868-8874, 2018. https://doi.org/10.1021/acssuschemeng.8b01213

[4] Pölczmann, G., Tóth, O., Beck, Á., Hancsók, J. "Storage Stability of Gas Oils Containing Waste Originated Biocomponent", Periodica Polytechnica Chemical Engineering, 58(2), pp. 157-163, 2014. https://doi.org/10.3311/PPch.7205

[5] Li, C., Zhang, L., Xiao, Z., Li, P., Liu, R., Chen, J., He, Z., Fu, J. "Production of Biodiesel Using a Vegetable Oil from Swida wilsoniana Fruits", Periodica Polytechnica Chemical Engineering, 59(4), pp. 283-287, 2015. https://doi.org/10.3311/PPch.7868

[6] Mika, L. T., Cséfalvay, E., Horváth, I. T. "The role of water in catalytic biomass-based technologies to produce chemicals and fuels", Catalysis Today, 247, pp. 33-46, 2015. https://doi.org/10.1016/j.cattod.2014.10.043

[7] Zöldy, M. "Automotive Industry Solutions in Response to European Legislative Emission Regulation Challenge", Science Future of Lithuania, 1(6), pp. 33-40, 2009.

https://doi.org/10.3846/mla.2009.6.07

[8] Bereczky, Á., Török, Á. "International literature review on the possibilities of biodiesel production", Periodica Polytechnica Transportation Engineering, 39(1), pp. 31-37, 2011. https://doi.org/10.3311/pp.tr.2011-1.06

[9] Žaglinskis, J., Rapalis, P., Lazareva, N. "An overview of Natural Gas Use in Ships: Necessity and Engine Supply", Periodica Polytechnica Transportation Engineering, 46(4), pp. 185-193, 2018. https://doi.org/10.3311/PPtr.11708

[10] Rimkus, A., Matijošius, J., Bogdevičius, M., Bereczky, Á., Török, Á. "An investigation of the efficiency of using $\mathrm{O}_{2}$ and $\mathrm{H}_{2}$ (hydrooxile gas -HHO) gas additives in a ci engine operating on diesel fuel and biodiesel", Energy, 152, pp. 640-651, 2018. https://doi.org/10.1016/j.energy.2018.03.087

[11] Hancsók, J., Krár, M., Magyar, Sz., Boda, L., Holló, A., Kalló, D. "Investigation of the production of high cetane number bio gas oil from pre-hydrogenated vegetable oils over Pt/HZSM22/ $\mathrm{Al}_{2} \mathrm{O}_{3} "$, Microporous and Mesoporous Materials, 101(1-2), pp. 148-152, 2007. https://doi.org/10.1016/j.micromeso.2006.12.012

[12] European Automobile Manufacturers' Association "ACEA position concerning diesel that might contain more than $7 \%$ FAME", [online] Available at: https://www.acea.be/publications/article/ acea-position-concerning-diesel-that-might-contain-more-than-7fame [Accessed: 22 April 2019]
[13] Zöldy, M. "Ethanol - Biodiesel - Diesel Blends as a Diesel Extender Option on Compression Ignition Engines", Transport, 26(3), pp. 303-309, 2011. https://doi.org/10.3846/16484142.2011.623824

[14] Barabás, I., Todoruţ, A., Băldean, D. "Performance and emission characteristics of an CI engine fueled with diesel-biodieselbioethanol blends", Fuel, 89(12), pp. 3827-3832, 2010. https://doi.org/10.1016/j.fuel.2010.07.011

[15] Mahmudul, H. M., Hagos, F. Y., Mukhtar, N. A., Mamat, R., Abdullah, A. A. "Effect of Alcohol on Diesel Engine Combustion Operating with Biodiesel-Diesel Blend at Idling Conditions", In: IOP Conference Series: Materials Science and Engineering, Penang, Malaysia, 318, 2018, article ID: 012071. https://doi.org/10.1088/1757-899X/318/1/012071

[16] Jamrozik, A. Tutak, W., Pyrc, M., Sobiepański, M. "Effect of Diesel-Biodiesel-Ethanol Blend on Combustion, Performance, and Emissions Charackteristics on a Direct Injection Diesel Engine", Thermal Science, 21(1), pp. 591-604, 2017. https://doi.org/10.2298/TSCI160913275J

[17] Asfar, K. R., Al-Rabadi, T. H. "Fuel Blends in Compression Ignition Engine", In: $1^{\text {st }}$ International Energy Conversion Engineering Conference, Session: FREPS-4: Alternative Fuels for Power Systems, Portsmouth, Virginia, 2003, article ID: AIAA 2003-6027. https://doi.org/10.2514/6.2003-6027

[18] Al-Hasan, M. I., Al-Momany, M. "The Effect of Iso-butanol-diesel Blends on Engine Performance", Transport, 23(4), pp. 306-310, 2018. https://doi.org/10.3846/1648-4142.2008.23.306-310

[19] Laza, T., Kecskés, R., Bereczky, Á., Penninger, A. "Examination of burning processes of regenerative liquid fuel and alcohol mixtures in diesel engine", Periodica Polytechnica Mechanical Engineering, 50(1), pp. 11-26, 2006.

[20] Bereczky, Á., Laza, T. "Influence of higher alcohols on the emissions of diesel engine operated with rape seed oil", presented at $4^{\text {th }}$ European Combustion Meeting, Vienna, Austria, Apr. 14-17, 2009.

[21] Karabektas, M., Hosoz, M. "Performance and emission characteristics of a diesel engine using isobutanol-diesel fuel blends", Renewable Energy, 34(6), pp. 1554-1559, 2009. https://doi.org/10.1016/j.renene.2008.11.003

[22] Miers, S. A., Carlson, R. W., McConnell, S. S., Ng, H. K., Wallner, T., Esper, J. L. "Drive Cycle Analysis of Butanol / Diesel Blends in a Light-Duty Vehicle", SAE Techinal Paper Series, Technical Paper: 2008-01-2381, 2008. https://doi.org/10.4271/2008-01-2381

[23] SlideShare "BP-DuPont biofuels fact sheet", [online] Available at: https://www.slideshare.net/BPfanpage/bpdupont-biofuels-fact-sheet [Accessed: 24 April 2019]

[24] Smith, J. L., Workman, J. P. "Alcohol for Motor Fuels", Farm \& Ranch Series: Equipment, Fact Sheet No. 5.010, 2014.

[25] Vojtisek-Lom, M., Beránek, V., Mikuška, P., Křůmal, K., Coufalík, P., Sikorová, J., Topinka, J. "Blends of butanol and hydrotreated vegetable oils as drop-in replacement for diesel engines: Effects on combustion and emissions", Fuel, 197, pp. 407-421, 2017. https://doi.org/10.1016/j.fuel.2017.02.039 
[26] Rakopoulos, D. C., Rakopoulos, C. D., Giakoumis, E. G. "Impact of properties of vegetable oil, bio-diesel, ethanol and $n$-butanol on the combustion and emissions of turbocharged HDDI diesel engine operating under steady and transient conditions", Fuel, 156, pp. 1-19, 2015.

https://doi.org/10.1016/j.fuel.2015.04.021

[27] International Organization for Standardisation "ISO/DIS 3104 Petroleum products - Transparent and opaque liquids Determination of kinematic viscosity and calculation of dynamic viscosity", ISO, Geneva, Switzerland, 1994, Revised: 2000.

[28] Zöldy, M., Hollo, A., Thernesz, A. "Butanol as a Diesel Extender Option for Internal Combustion Engines", SAE Technical Paper Series, Technical Paper: 2010-01-0481, 2010. https://doi.org/10.4271/2010-01-0481

[29] DIN German Institute for Standardization "DIN EN ISO 2719 Determination of flash point - Pensky-Martens closed cup method", DIN, Berlin, Germany, 2003, Revised: 2016.

[30] International Organization for Standardization "ISO 5165:1998 Petroleum products - Determination of the ignition quality of diesel fuels - Cetane engine method", ISO, Geneva, Switzerland, 1998, Revised: 2017.
[31] European Committee for Standardization "CEN - EN 590: Automotive fuels - Diesel - Requirements and test methods", CEN, Brussels, Belgium, 2013.

[32] Hungarian Standardization Institute "MSZ EN 116:1999 Diesel and domestic heating fuels. Determination of cold filter plugging point", MSZT, Budapest Hungary, 1999, Revised: 2000.

[33] International Organization for Standardization "ISO 12156-1:2016 Diesel fuel - Assessment of lubricity using the high-frequency reciprocating rig (HFRR) - Part 1: Test method", ISO, Geneva, Switzerland, 2016, Revised: 2018.

[34] Caprotti, R., Jansen, E. B. M., Kraft, T., Woodall, K. "Laboratory Test for Distributor Type Diesel Fuel Pumps - CEC PF032 Code of Practice", SAE Technical Paper Series, Technical Paper: 200401-2016, 2004. https://doi.org/10.4271/2004-01-2016

[35] International Organization for Standardization "ISO 12185:1996 Crude petroleum and petroleum products - Determination of density — Oscillating U-tube method", ISO, Geneva, Switzerland, 1996. 